\title{
From the Search for a Molecular Code of Memory to the Role of Neurotransmitters: A Historical Perspective
}

\author{
Georges Chapouthier \\ "Vulnérabilité, Adaptation et Psychopathologie", CNRS UMR 7593, Hôpital Pitié- \\ Salpêtrière, 91 Bd de l'Hôpital, 75634 Paris cedex 13, France
}

\begin{abstract}
SUMMARY
The history of the neurochemistry of mnesic processes can be divided into two main periods: the first (1946-1978) was inspired by the results of molecular genetics, providing evidence for storage of hereditary information in the DNA of genes. Therefore, the chemical bases for memory were investigated in the macromolecules of the brain. Such attempts were relatively unsuccessful, which led to a second period (starting in 1978) with the research emphasizing, in a less ambitious way, the role of the molecular correlates of mnesic processes, in particular in the main transmitter systems of the brain.
\end{abstract}

\section{KEYWORDS}

memory, learning, neurochemistry, transmitter, code

\section{INTRODUCTION}

The search for the biochemical bases of memory processing has been a long quest. The first steps can be traced back to the post World War II

Reprint requests to: Georges Chapouthier, Vulnérabilité, Adaptation et Psychopathologie", CNRS UMR 7593, Hôpital Pitié-Salpêtrière, 91 Bd de l'Hôpital, 75634 Paris cedex 13, France; e-mail: chapout@ext.jussieu.fr

(C) 2004 Freund \& Pettman, U.K. years, when certain theoreticians suggested that macromolecules might be involved in the coding of memory-related events. One of the first hypotheses was made as early as 1946 by the physician Gérard Morin (1946) who proposed a paradigm in which the bases for memory traces were considered to be analogous to "the genes of the chromosomes" (p. 23). A similar theory, linking memory traces to macromolecules, was later formulated by Monné (1948). Although these were brilliant hypotheses provided by scientific 'prophets', in science, only experimental evidence can lead to solid assumptions. The first proper experimental studies were conducted by Hyden (1959) some 10 years later and marked the real beginning of the approach to a 'biochemistry of mnesic processes'.

\section{Search for a molecular code of memory}

The first research studies were based on ideas emerging with advances in molecular genetics. As clear proof had been presented to show that hereditary information is stored chemically in the DNA molecules of the chromosomes, several authors assumed that the information acquired by the brain-namely memory-could also be stored chemically in brain macromolecules. If DNA is excluded, the reason being that DNA is involved in genetic coding, then two categories remain as candidates and have been extensively studied: (messenger) RNA and protein (Chapouthier, 1983). The first is the study by Hyden (1959) cited 
above. Hyden analyzed brain nuclei that are known to play a role in the control of postural balance (Deiters' nuclei) by testing rats with a learning task involving balance control. Hyden observed a change in the nuclei after learning, seen as a change in the proportion of purine versus pyrimidine bases in the RNA. He suggested that this change in the proportional balance, interpreted as a change in the RNA sequence, could be the biochemical trace of memory processing.Following Hyden's pioneer work, a number of authors produced evidence of changes in brain macromolecules after learningchanges observed in several brain areas (Chapouthier, 1974). Such studies can be divided into three main areas of investigation: chemical analyses of brain macro-molecules after learning, studies of the effect of antibiotics on learning, and attempts to produce 'memory transfer' by chemical means.

Chemical analyses of brain macromolecules followed Hyden's path and included assays, using several methods, either direct or indirect, measuring chemical changes in various brain areas occurring after learning (Byrne, 1970). Direct methods were straightforward assays; indirect methods used reactive precursors: a radioactive precursor of RNA (a labeled nucleotide) or protein (a labeled amino acid) was administered to the test animal, and any increase in radioactivity after learning was investigated in the corresponding macromolecule produced (RNA or protein). Any increase observed was interpreted as the sign of the macromolecule being synthesized during (or because of) the learning process and therefore seen as indirect proof of its involvement in memory processing.

Antibiotics were also used to establish a correlation between protein synthesis and learning (Agranoff, 1965; Flexner, 1963). Antibiotics are known to impair the synthesis of macromolecules (RNA or protein) in the process known as protein synthesis. If the administration of high doses directly to the brain clearly impaired memory, then this impairment could then be interpreted as indirect evidence for brain macromolecules playing a role in memory.

Searches for memory transfers by chemical means were based on the crude assumption that a trained brain, administered directly to a naive recipient, would transfer certain memorized elements (Chapouthier, 1973). Summaries of the many experiments using the three approaches, together with critical assessments, can be found in the literature (Byrne, 1970; Ungar, 1970; Chapouthier, 1983, 2001). The initial findings in this field of investigation-concluding that a chemical basis for memory had been clearly established-gave rise to much criticism (see Chapouthier, 1983, 2001).

For the first method, chemical analyses of brain macromolecules after learning, numerous findings have been interpreted in different ways: a brain at work (which is the case of a learning brain) is the site, or theater, of tremendous biochemical changes, including changes in the categories of the RNA or protein that are synthesized. The chemical changes observed by Hyden (1959) and by later researchers can thus be related to brain activity during learning but not necessarily to the coding of specific memory traces. The interpretation of these results was therefore likely due to nonspecific effects.

The second method, involving the use of antibiotics, encountered the same kind of objection: if antibiotics administered to the brain did impair learning, which was demonstrated in several studies, then this finding proves that protein synthesis has "something to do with" memory processes but does not prove that a specific molecule is able to code for a specific memory. Here again, the interpretation of the data was probably due to nonspecific effects.

\section{The question of memory transfers}

The third method, called memory transfers, was more likely to demonstrate specific effects. If trained brain extracts were in fact able to transfer memorized pieces of information from one animal 
to another, then a strong argument could thus be given for the existence of 'memory molecules'. This dramatic method does, however, come up against several methodological objections that will not be reviewed extensively here (Chapouthier, 2001).

A first attempt to use this method was made by McConnell $(1959,1962)$ and his research group on planarian worms, and will be presented below. Several reports can also be found in McConnell's journal, entitled The Worm Runner's Digest, kept from 1959 to 1979 . The journal originally began as a laboratory documentary record, mixing serious scientific reports with lab jokes. In October 1964, the diary turned into a more lavish publication. In 1967, one half kept the name of The Worm Runner's Digest and continued to publish humorous articles, while the other half took the more serious title of the Journal of Biological Psychology. The two halves combined to form a whole, and the journal could be turned upside down and read from both sides!

Planarian worms are capable of complete regeneration if cut into two or more pieces. They can also assimilate into their body ingested pieces of other animals of the same species, without major digestion; the phenomenon is similar to grafting, but is known as cannibalism. McConnell et al. $(1959,1962)$ claimed to have taught planaria several conditioning procedures (Thompson, 1955). The research group argued that the conditioning remained after regeneration (McConnell, 1959) and using the cannibalism procedure could be transmitted from one (trained) animal to another (untrained) one (McConnell, 1962). The authors believed, however, that whereas regeneration could occur in water containing RNAse (an enzyme destroying RNA), the memory of this conditioning disappeared (Corning, 1961). Yet, RNA directly extracted from trained planarians seemed to be capable of 'transferring' the acquired conditioning to naive animals (Jacobson, 1966). From all these data, McConnell's group concluded that the memory of planarians was coded in RNA molecules and that these 'memory molecules' could occasionally be transmitted from one worm to another.

As is often the case in work involving animal behavior, several biases were subsequently found in the studies and tended to undermine the provocative conclusions (Chapouthier, 1968). The conditioning of planarians appears to be a more complex phenomenon than already thought. Such conditioning is often restricted to partial responses, far from the $100 \%$ responses of higher animals, and sometimes develops into a strange phase known as 'rejection' of the reinforced goal. Yet the cannibalism itself was shown to modify certain behavioral responses in a way that could appear to be conditioning-for example, hungry planarians, as could be the case for cannibalistic planarians, become more sensitive to light, which also happened to be one of the responses for conditioning chosen by McConnell et al. (Chapouthier, 1967).

These pioneer studies had induced similar results in vertebrates (Chapouthier, 1968; Ungar, $1970,1971)$. In 1965, a number of research groups (for example, Fjerdingstad, Reinis, Rosenblatt, and Ungar) published data suggesting that it was possible to transfer memorized information by implanting brain extracts from donor rats into recipient rats. With the exception of Ungar, all the authors followed McConnell's assumptions and used RNA extracts, but it was shown later (Lambert, 1967) that RNA could not be the agent responsible for the behavioral changes observed. Although the RNA extracts were certainly active, the effects on the planarians were probably caused by 'impurities' in the extracts. This aspect was clearly demonstrated by the outstanding work conducted by Georges Ungar (1906-1977). Ungar showed that the agents responsible for the change were probably peptides, namely small proteins. In fact, the apparent 'memory transfer' effects disappeared with either purified RNA (Lambert, 1967) or brain extracts treated with chymotrypsin, 
an enzyme able to digest proteins (Ungar, 1965). Ungar (1970) then isolated from rat brain a cerebral peptide that he named scotophobin, which seemed to transfer learned fear of the dark when administered to recipient mice. When chemically synthesized, the same peptide was later shown to evoke the same behavioral actions as the natural brain peptide: mice treated with this peptide avoided dark areas. Ungar (1976) thus claimed to have isolated the first word in a chemical code for memory.

There is now a consensus on the interest of this original peptide, which is able to modify anxious behavior patterns in mice. The question arises, however, as to what the compound actually does. Is it, as suggested by Ungar, part of a chemical code for memory? Or is it simply a molecule able to modify emotions? This alternate hypothesis had already been proposed by Agranoff in 1970 at the meeting in Albuquerque, New Mexico, wher e Ungar (1970) presented his first data on scotophobin. Later work by Misslin et al. (1978) clearly demonstrated that scotophobin had a selective action on emotive (anxious) mice, inducing marked avoidance of dark corners. The compound was therefore more likely to be an anxiolytic molecule rather than a chemical memory code word.

We can assume that, historically, the 1978 paper by Misslin et al. terminated, at least for the time being, the quest for a chemical code for memory. This conclusion does not mean that no molecule will ever be found to be involved in memory coding but rather suggests that if molecules do have a role to play in memory coding, then that role is likely to be more complex than that initially suggested by Hyden (1959) and Ungar (1970). The idea of memory molecules acting without any direct link to the structural organization of the nerve pathways, or without structural interactions with networks such as the limbic system, seems unlikely. The structural organization of the nervous system and nerve pathways has led to modern approaches to the biochemistry of memory processes involving the action of brain neurotransmitters.

\section{Chemical correlates of mnesic processes}

The work of Misslin et al. (1978) thus seems to have put an end (at least temporarily) to the ambitious search for a molecular code for memory in the brain. Since then, research has switched direction to tackle less ambitious goals. The purpose is no longer to find molecular codes for memory but instead to establish general correlations between mnesic events and brain biochemistry. This type of work was already being conducted before 1978, during the great period of the "memory coding investigations", but was not then considered the main way of achieving rapid progress in the area. This correlative approach is now the key path for investigating the biochemistry of learning and memory.

Among the dozens of compounds identified as cerebral neurotransmitters, several play an important role in memory processing (Chapouthier, 1989), of which four are of key importance: acetylcholine, GABA, glutamic acid, and norepinephrine. In addition to these 'classic' transmitters are several peptides, but their role as transmitters has not been clearly established, although, to a certain extent, they are the logical follow-on from the peptides previously shown to be involved in chemical memory coding.

Acetylcholine. Acetylcholine, an excitatory transmitter and the most important in the cerebral cortex, has been extensively studied as cholinergic deficiency is observed in dementias with memory impairment, the most famous being Alzheimer's disease (Bartus, 1982). Evidence for the involvement of cholinergic processes in memory had already been provided in animal studies: in 1969 , when Deutsch, conducting experimental pharmacological interventions in rats, showed that for learning to occur properly, an optimal quantity of acetylcholine was needed in the synapses 
(Deutsch, 1969). The involvement of acetylcholine in memory processes was later demonstrated in quite different learning situations, such as imprinting in chicks (Chapouthier, 1982), learning in mice (Marighetto, 1993), and Parkinson's disease in humans (Dubois, 1983; Bosboom, 2003; Pimlott, 2004).

GABA. Gamma amino-butyric acid, or GABA, is the most important inhibitory transmitter of the nervous system where it 'slows down' the action (Chapouthier, 1992). Compounds that increase GABA action therefore have sedative, anticonvulsant, anxiolytic, or amnestic effects (Curran, 1986; Chapouthier, 2002), whereas compounds that decrease GABA action have stimulant, convulsive, anxiogenic, and promnestic effects. At low doses, GABA-increasing drugs improve learning (Venault, 1986, 1986; Krazem, 2001; Chapouthier, 2002).

Glutamate. Glutamate is an excitatory transmitter playing a key role in the hippocampus, which is involved in several aspects of memory processing. Plasticity phenomena, such as longterm synaptic potentiation with glutamate treatment, have been proposed as memory models by several authors (Bliss, 1993; Laroche, 1998; Homayoun, 2004).

Norepinephrine. Several compounds affecting the norepinephrine system also modify learning abilities (Kety, 1970; Martinez, 1986; Chapouthier, 1989). Interesting work in this field has focused on the locus coeruleus, a small nucleus of the brain stem carrying norepinephrine fibers to the cerebral cortex. The 'coeruleo-cortical' system, which is involved in attention processes, seems to play an essential role in the fixing and recall of memorized information (Sara, 1985).

Peptides. A number of peptides that are likely to have an action on nerve cells can modulate memory processes. In the Netherlands, De Wied (1971; De Wied et al., 1975) produced evidence that peptides derived from hormones such as $\mathrm{ACTH}$ or $\mathrm{ADH}$, but devoid of any hormonal effect (being shorter peptides than the active hormones), can either facilitate or impair learning (depending on the compound) in simple training situations. Alexinsky (1987) and Alliot (1993) and their research teams were then able to confirm the data in complex training situations requiring rats to master cognitive rules. Peptides with morphinelike effects, for example, the enkephalins and endorphins (Rossier, 1982), also have learningenhancing or learning-impairing properties (Chapouthier, 1983). Ungerer et al. (1988) in Strasbourg studied the plant Datura stramonium, used by African sorcerers for its amnestic powers, and isolated an amnestic dipeptide: gamma-Lglutamyl-L aspartate. The peptides identified during initial research into memory, for example, scotophobin, have seen their identity as 'chemical memory words' challenged, but still have an indirect action on learning (for example, via emotional mechanisms, as previously mentioned for scotophobin). Other peptides were proposed after scotophobin was isolated (Chapouthier, 1983), and all these 'memory transfer peptides' can therefore be considered as having a 'new life' as 'learning enhancers' in a more modest view of the biochemistry of memory processes.

\section{CONCLUSION}

Historically, the quest to find neurochemical bases for memory processes can be divided into two successive periods. Until 1978, the emphasis was on the search for a molecular code of memory traces, similar to the coding for genes and DNA. Authors such as Hyden (1959) and Ungar (1970) soon discovered putative 'memory' macromolecules. Experimental biases gradually led to these studies being abandoned, and specifically after 1978 when Misslin et al. interpreted some of Ungar's findings as being emotional processes, not directly related to memory coding. More 'modest' research followed, focusing on the involvement of 
the main transmitter systems of the brain in memory processes but not in memory coding. This research still continues and is currently very active. Most of the articles in the present issue are devoted to the results of this research.

From a theoretical point of view, it is interesting to note that data from the first periodfor example, the importance of protein synthesis and the possible emotional impact of scotophobinhave been 'recycled' for interpretations in the second period. Protein synthesis, for example, is now seen as a nonspecific phenomenon, not directly linked to memory coding, yet remains an important event in the first stages of memory processing, both when awake and during paradoxical sleep (Chapouthier, 2001). It is therefore satisfying to realize that whereas scientific 'discoveries' might not achieve the immediate and expected goals, they still contribute to the general advancement of knowledge.

\section{REFERENCES}

Agranoff BW, Davis RE, Brink JJ. 1965. Memory fixation in goldfish. Proc Natl Acad Sci USA 54; 788-793.

Alexinsky, T, Alliot J. 1987. Vasopressin injections impair working memory in delayed matching to sample task in rats. Behav Neural Biol 48, 167182.

Alliot J, Nauton P, Bruhat MA. 1993. Administration of LHRH analog can improve working memory in aged females. Psychoneuroendocrinology 18: 543-550.

Bartus RT, Dean RLI, Beer S, Lippa AS. 1982. The cholinergic hypothesis of geriatric memory dysfunction. Science 217: 408-417.

Bliss T, Collingridge G. 1993. A synaptic model of memory: long-term potentiation in the hippocampus. Nature 361: 31-39.

Bosboom J, Stoffers D, Wolters E. 2003. The role of acetylcholine and dopamine in dementia and psychosis in Parkinson's disease. J Neural Transm Suppl 65: 185-195.
Byrne L, ed. 1970. Molecular Approaches to Learning and Memory. New York, NY, USA/London, UK: Academic Press.

Chapouthier G. 1967. Taux de réponse à la lumière en relation avec le cannibalisme chez la planaire Dugesia lugubris [Level of response to the light in relation to cannibalism in the planarian Dugesia lugubris]. C R Acad Sci Hebd Seances Acad Sci D 265: 2047-2050. French.

Chapouthier G. 1968. Le transfert des molécules de mémoire chez les vertebras [The transfer of memory molecules in vertebrates]. Annee Biol 7: 275-285. French.

Chapouthier G. 1973. Behavioral studies of the molecular basis of memory. In: Deutsch JA, ed, The Physiological Basis of Memory. New York, NY, USA/London, UK: Academic Press; 1-25.

Chapouthier G. 1974. Aspects chimiques de l'apprentissage. Rev Questions Scientifiques 145: 279-300. French.

Chapouthier G. 1983. Protein synthesis and memory. In: Deutsch JA, ed, The Physiological Basis of Memory. Academic Press, New York, NY, USA London, UK: Academic Press; 1-47.

Chapouthier G. 1989. A la recherche d'une biochimie de la mémoire, Mémoire et vieillissement: approche méthodologique. Doin 7-9. French.

Chapouthier G. 2001, L'aventure de la biochimie de la mémoire. [History of biochemistry of the memory] Cahiers Alfred Binet 667: 69-78. French.

Chapouthier G, Lecanuet JP, Ebel A. 1982. Brain cholinergic mechanisms during imprinting in chicks. Behav Brain Res 5: 95-96.

Chapouthier G., Legrain D, Spitz S. 1968a. La planaire en tant qu'animal de laboratoire dans les recherches psychophysiologiques. Exp Anim 1: 169-280. French.

Chapouthier G, Martin B. 1992. $\beta$-carbolines: from memory towards genetics. Eur Bull Cognit Psychol 12, 423-458.

Chapouthier G, Pallaud B, Ungerer A. 1968b, Relations entre deux réactions des planaire face à une discrimination droite-gauche. [Relation between two reactions of Planaria facing right-left discrimination] C R Acad Sci Hebd Seances Acad Sci D 266: 905-907. French.

Chapouthier G, Venault P. 2002. GABA-A receptor complex and memory processes. Curr Top Med Chem 2: 841-851. 
Corning WC, John ER. 1961. Effect of ribonuclease on retention of conditioned response in regenerated planarians. Science 134: 1363-1365.

Curran H. 1986. Tranquillising memories: a review of the effects of benzodiazepines on human memory. Biol Psychol 23: 179-213.

De Wied D. 1971. Long term effect of vasopressin on the maintenance of a conditioned avoidance response in rats. Nature 232: 58-60.

De Wied D, Witter A, Greven HM. 1975. Behaviourally active ACRH analogues. Biochem. Pharmacol 24: 1463-1468.

Deutsch JA. 1969. The physiological basis of memory. Ann Rev Psychol 20; 85-104.

Dubois B, Ruberg M, Javoy-Agid F, Ploska A, Agid Y. 1983. A subcortical cholinergic system is affected in Parkinson's disease. Brain Res 288: 213-218.

Flexner JB, Flexner LB, Stellar E. 1963. Memory in mice as affected by intracerebral puromycin. Science 141: 57-59.

Homayoun H, Stefani MR, Adams BW, Tamagan GD, Moghaddam B. 2004. Functional interaction between NMDA and mGlu5 receptors: effects on working memory, instrumental learning, motor behaviors, and dopamine release. Neuropsychopharmacology 29:1259-1269.

Hyden H. 1959. Biochemical Changes in Glial Cells and Nerve Cells at Varying Activities, Biochemistry of the Central Nervous System, Vol. 3. Oxford, UK: Pergamon Press; 64-89.

Jacobson AL, Fried C, Horowitz SD. 1966. Planarians and memory. Nature 209: 599-601

Kety SS. 1970. The biogenic amines in the central nervous system: their possible roles in arousal, emotion and learning. In: Schmitt FO, ed, The Neurosciences. Second Study Program. New York, NY, USA: Rockefeller University Press; 324-336.

Krazem A, Borde N, Beracochea D. 2001. Effects of diazepam and $\beta-C C M$ on working memory in mice: relationship with emotional reactivity. Pharmacol Biochem Behav 68: 235-244.

Lambert R, Saurat M. 1967. RNA et transfert d'apprentissage: une réplique d'expérience. Bull CERP 16: 435-438. French.

Laroche S. 1998. Les mécanismes de la mémoire. Pour la Science 254: 94-101.

Marighetto A, Micheau J, Jaffard R. 1993. Relationships between testing-induced alterations of hippocampal cholinergic activity and memory performance on two spatial tasks in mice. Behav Brain
Res 56: 133-144.

Martinez JLJ. 1986. Memory: Drugs and Hormones. In: Martinez JLJ, Kesner RP, eds, Learning and Memory, a Biological View. New York, NY, USA: Academic Press; 127-163.

McConnell JV. 1962. Memory transfer through cannibalism in planarians. J Neuropsychiatr 3 Suppl 1: 42-48.

McConnell JV, Jacobson AL, Kimble DP. 1959. The effects of regeneration upon retention of a conditioned response in the planarian. J Comp Physiol Psychol 52: 1-5.

Misslin R, Ropartz P, Ungerer A, Mandel P. 1978. Non-reproducibility of the behavioral effects induced by scotophobin. Behav Proc 3: 45-56.

Monné L. 1948. Functioning of the cytoplasm. Adv Enzym Relat Subj Biochem 8: 1-69.

Morin G. 1946. Quelques considérations sur les rêves au cours du travail digestif. Thèse de Médecine, Faculté de Médecine de Marseille. French.

Pimlott S, Piggott M, Owens J, Greally E, Court J, Jaros E, et al. 2004. Nicotinic acetylcholine receptor distribution in Alzheimer's disease, dementia with Lewy bodies, Parkinson's disease, and vascular dementia: in vitro binding study using 5-[(125)i]-a85380. Neuropsychopharmacology 29: 108-116.

Rossier J, Chapouthier G. 1982. Les opiums du cerveau: enképhalines et endorphines. La Recherche 13: 1296-1306.

Sara SJ. 1985. The locus coeruleus and cognitive function: attempts to relate noradrenergic enhancement of signal/noise in the brain to behavior. Physiol Psychol 13: 151-162.

Thompson R, McConnell JV. 1955. Classical conditioning in the planaria Dugesia dorotocephala. $\mathrm{J}$ Comp Physiol Psychol. 48: 65-68.

Ungar G, ed. 1970. Molecular Mechanisms in Memory and Learning. New York, NY, USA/London, UK; Plenum Press.

Ungar G. 1976. A la recherche de la mémoire. Paris, France: Fayard.

Ungar G, Chapouthier G. 1971. Mécanismes moléculaires de l'utilisation de l'information par le cerveau. Année Psychologique 1: 153-183. French.

Ungar G, Ho IK, Galvan L. 1970. Isolation of a behavior-inducing peptide from brain. Trans Am Soc Neurochem 1.

Ungar G, Oceguera-Navarro C 1965. Transfer of habituation by material extracted from brain. Nature 207: 301-302. 
Ungerer A, Schmitz-Bourgeois M, Melan C, Boulanger Y, Reinbolt J, Amiri I, et al. Gamma-1988. L-glutamyl-L-aspartate induces specific deficits in long-term memory and inhibits $\left({ }^{3} \mathrm{H}\right)$ glutamate binding on hippocampal membranes. Brain Res 446: 205-211.

Venault P, Chapouthier G, Prado de Carvalho L, Simiand J, Morre M, Dodd RH, et al. 1986a. Benzodiazepine impairs and $\beta$-carboline enhances performance in learning and memory tasks. Nature 321: 864-866.

Venault P, Prado de Carvalho L, Rossier J, Chapouthier G. 1986b. Anxiogenic and memory enhancing effects of drugs acting at the GABAbenzodiazepine receptor complex. In: Matthies hj, ed, Learning and Memory-Mechanisms of Information Storage in the Nervous System., Oxford, UK: Pergamon Press; 387-390. 

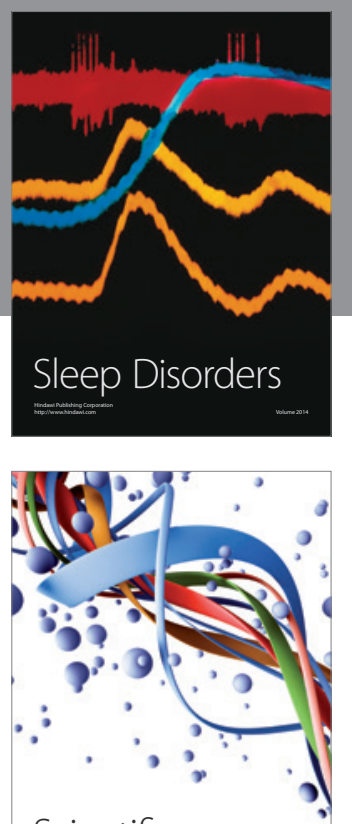

Scientifica
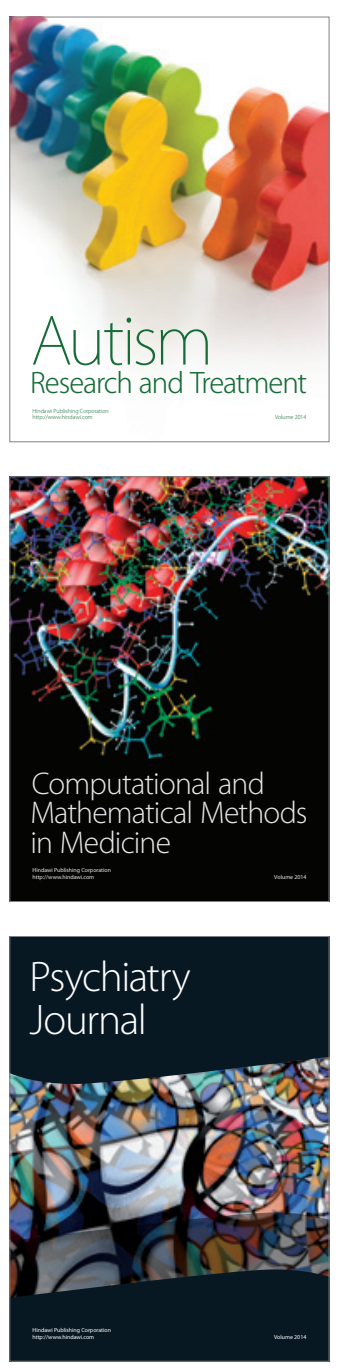
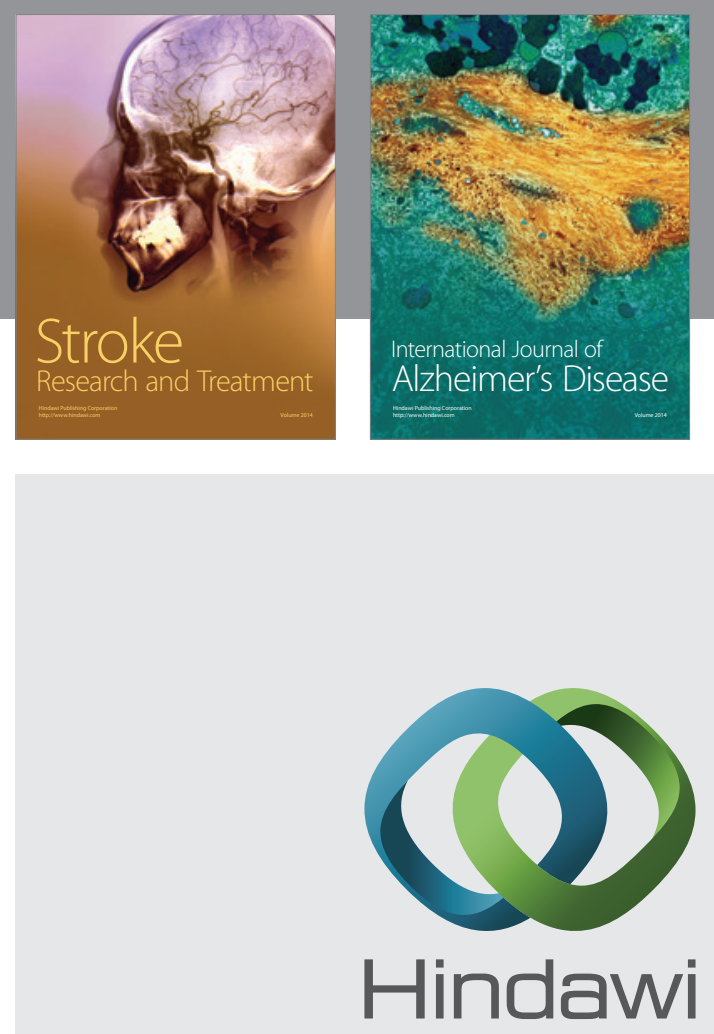

Submit your manuscripts at

http://www.hindawi.com
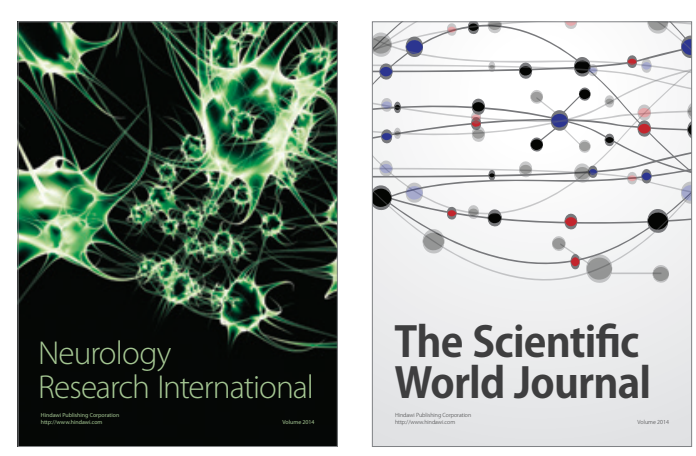

The Scientific World Journal

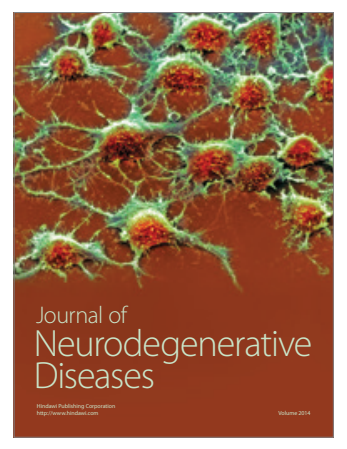

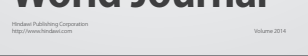

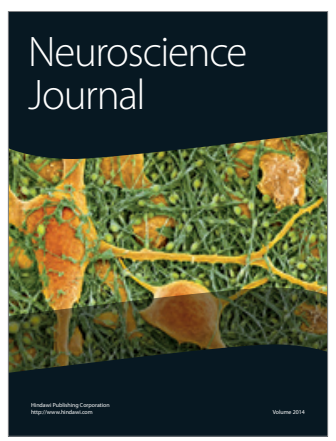

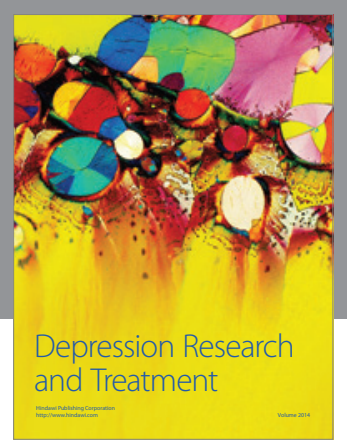
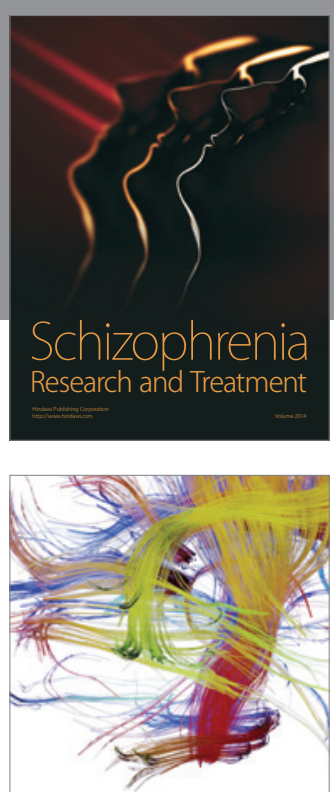

Brain Science

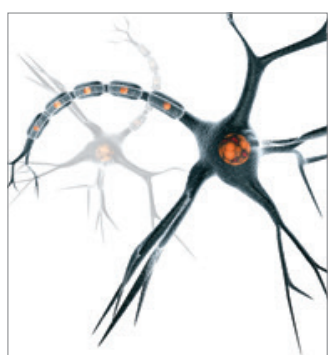

Neural Plasticity
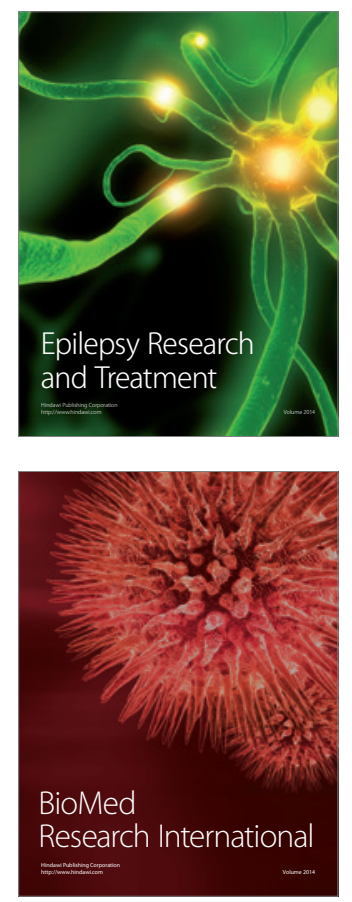

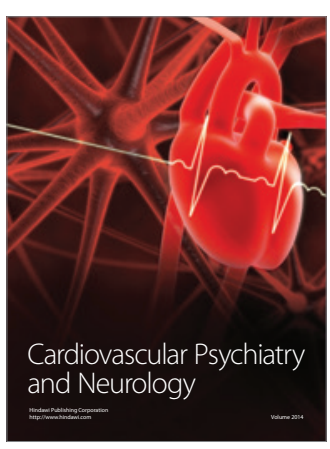

Parkinson's

Disease
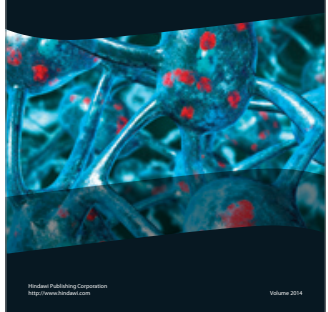